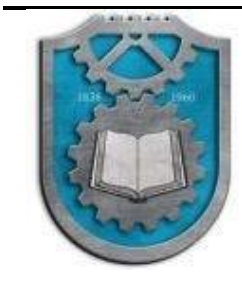

MOBILITY \& VEHICLE MECHANICS

DOI: $10.24874 / \mathrm{mvm} .2021 .47 .03 .05$

UDC: 620.193 .95

\title{
THE EFFECT OF CORROSION ON A STRUCTURAL INTEGRITY AND VEHICLE SAFETY
}

Valentina Golubović-Bugarski ${ }^{1}$, Snežana Petković ${ }^{2}$ Gordana Globočki-Lakić3

Received in July $2020 \quad$ Revised in August $2020 \quad$ Accepted in March 2021

RESEARCH ARTICLE

\begin{abstract}
The problem of corrosion is a problem of global importance, and significant attention has been paid to this problem during last years. On the one hand, the effect of corrosion on a vehicle depends on how excessively the corrosion has spread to the structural element and, on the other hand, depends on the specific function of structural element where corrosion is found. Thus, safety of the vehicle might be significantly reduced if the corrosion spreads on the vital structural component of the vehicle. Even a small amount of corrosion that disrupts the continuity of the load bearing structure, can endanger the bearing capacity of a given structural component. A special problem from the aspect of safety is the corrosion of the vehicle frame (chassis). This paper presents an analysis of the effects of weakening of the frame due to corrosion on the predicted design bearing characteristics and safety operation parameters, which the vehicle possesses at the beginning of its service life. By reducing the dimensions of the vehicle frame due to corrosion, critical areas of the structure will ocurre, to which an additional attention should be paid during the design and control of the frame condition. The analysis was performed using the Solidworks Static Simulation program. Regarding that the occurrence of corrosion can weaken the load bearing structural elements and reduce the safety of the vehicle, it is necessary to improve the technical inspections of the vehicle and periodically check the condition of the vehicle in terms of corrosion and structural integrity.
\end{abstract}

KEY WORDS: vehicle corrosion, structural integrity, vehicle safety, technical inspection

(C) 2021 Published by University of Kragujevac, Faculty of Engineering

\footnotetext{
${ }^{I}$ Valentina Golubović Bugarski, University of Banja Luka, Faculty of Mechanical Engineering, Banja Luka, valentina.golubovic-bugarski@mf.unibl.org (*Corresponding author)

${ }^{2}$ Snežana Petković, University of Banja Luka, Faculty of Mechanical Engineering,Banja Luka snezana.petkovic@mf.unibl.org

${ }^{3}$ Gordana Globočki Lakić, University of Banja Luka, Faculty of Mechanical Engineering, Banja Luka, gordana.globocki-lakic@mf.unibl.org
} 


\section{UTICAJ KOROZIJE NA INTEGRITET STRUKTURE I SIGURNOST VOZILA}

REZIME: Problem korozije je problem od globalnog značaja, a poslednjih godina ovom problemu je posvećena značajna pažnja. S jedne strane, uticaj korozije na vozilo zavisi od toga koliko se korozija prekomerno proširila na element konstrukcije, a sa druge strane zavisi od specifične funkcije strukturnog elementa na kome se nalazi korozija. Stoga bi se sigurnost vozila mogla značajno smanjiti ako se korozija proširi na vitalnu konstrukcijsku komponentu vozila. Čak i mala korozije koja narušava kontinuitet nosive konstrukcije, može ugroziti nosivost date komponente konstrukcije. Poseban problem sa aspekta bezbednosti predstavlja korozija okvira vozila (šasije). U ovom radu je prikazana analiza uticaja slabljenja okvira usled korozije na predviđene projektne karakteristike ležaja i bezbednosne radne parametre, koje vozilo poseduje na početku svog radnog veka. Smanjenjem dimenzija okvira vozila zbog korozije, pojaviće se kritična područja konstrukcije, na šta treba obratiti dodatnu pažnju prilikom projektovanja i kontrole stanja okvira. Analiza je izvršena korišćenjem programa Solidworks Static Simulation. S obzirom da pojava korozije može oslabiti nosive konstrukcijske elemente i smanjiti sigurnost vozila, potrebno je poboljšati tehničke preglede vozila i povremeno proveravati stanje vozila u pogledu korozije i celovitosti konstrukcije.

KLJUČNE REČI: korozija vozila, integritet strukture, bezbednost vozila, tehnički pregled 


\title{
THE EFFECT OF CORROSION ON A STRUCTURAL INTEGRITY AND VEHICLE SAFETY
}

\author{
Valentina Golubović-Bugarski, Snežana Petković, Gordana Globočki-Lakić
}

\section{INTRODUCTION}

Corrosion that occurs on vehicles is a problem that endangers traffic safety and has an adverse financial effect on the economy of any country. Until the late 1950s, corrosion of motor vehicles was considered to be a problem that occurs exclusively in marine and coastal environments. However, in the following years, a large number of vehicles used within the continent areas were shown to corrode and become unusable in just a few years, and the reason for that was found in the intensive use of salt as protection against road icing in the winter [2]. Motor vehicles produced during the last decades have very little visible corrosion thanks to numerous technological improvements introduced in the process of vehicle design and production. However, the annual costs related to corrosion are still significant and still much can be done to reduce them. In 2002, the US Federal Highway Administration released a study [5] on the direct costs associated with metallic corrosion in the US industry. In 1998, the total annual direct cost of corrosion in the U.S. was ca. \$276 billion (ca. 3.2\% of the US gross domestic product). Broken down into five specific industries the economic losses are $\$ 22.6$ billion in infrastructure; $\$ 17.6$ billion in production and manufacturing; $\$ 29.7$ billion in transportation; $\$ 20.1$ billion in government; and $\$ 47.9$ billion in utilities. Corrosion is the natural process of gradual destruction of materials (usually a metal) by chemical and/or electrochemical reaction with environment in which the material is located. It causes measurable material changes and leads to corrosion damage. It is formed on the surface of the metal and spreads faster or slower from the surface to the depth, whereby the chemical composition and properties of the metal change. It occurs as a consequence of physical - chemical processes: a) when metal is in contact with an aggressive environment (metal - water, metal - acid, metal - air, metal - earth, etc.), b) in contact of dissimilar metals and c) on the contact surface of two metal grains with different composition or different voltage state. In the process of corrosion, the metal completely or partially dissolves or a precipitate forms on the metal surface (rust formed during corrosion of iron in a humid environment). Due to corrosion, in some cases the alloys decompose into components or the physical - chemical properties of metals and alloys change. Corrosion degrades the useful properties of materials and structures including strength, appearance and permeability to liquids and gases. The corrosion reaction can be represented in a simple way by the relation [3]: metal + environment $=$ corrosive product.

\section{TURNING MECHANISM}

According to the domination, corrosion can be uniform - over the entire surface of the metal product and local - only on certain metal surfaces. The most common type of corrosion of metal parts is uniform corrosion. It is present over the entire surface of a metal object which is in a contact with an aggressive environment. In the case of local corrosion, only certain parts of the surface of the material are subject to destruction. Corrosion can be concentrated locally to form a pit or crack. It is so-called pitting which causes destruction of individual zones and is unevenly distributed over the surface. Characteristic of pitting corrosion is the appearance of holes that penetrate into the depth of metal parts. In cases when the contact of metals of different electrical potential is dominant in the presence of electrolytes, contact (galvanic) corrosion will occur. 
The most unfavorable form of corrosion is intergranular corrosion because it occurs at the boundaries of metal grains and penetrates very quickly and deeply into the metal. Due to corrosion, the bond of crystal grains weakens, and thus the metal parts losing its strength. There is corrosion without mechanical load and corrosion under mechanical load. Corrosion without mechanical load is divided into two subgroups, depending on the physical state. The first is corrosion in the watery medium (contact, pitting and corrosion in the gaps), and the second - corrosion in the gaseous medium (chemically induced hydrogen occurrence, oxidation and formation of deposits). Corrosion under mechanical load in the watery medium refers to stress corrosion, corrosive fatigue, erosion corrosion. In order to any of these corrosion be initiated, it is necessary that, in addition to the material and the working environment, an external load also participates, where cracks can occure as a consequence of the action of the load. In most cases, the corrosion reaction is of electrochemical character, and it can also occur due to the action of chemical and physical processes. Thus, according to the reaction mechanism, one can distinguish two types of corrosion - chemical and electrochemical. Chemical corrosion is caused by the interaction of metals and gases at raised temperatures (gas corrosion), and electrochemical - by the action of electrolytes on the metal, which is the most common form of corrosion.

\subsection{Electrochemical corrosion}

Most metal structures are in contact with air, which also contains water vapor, carbonic acid, sulfur-based gases and other impurities that dissolve in moisture droplets. The surface of such exposed structures is covered with moisture, saturated salts, bases, acids, or a layer of electrolyte that directly participates in the process of electrochemical corrosion of metals. It is based on the ability of the metal to ionize (release electrons) and the corresponding medium (electrolyte). The measure of this phenomenon is the electrode potential, which is defined as the difference between the potential of a metal and the so-called standard (reference) hydrogen electrodes, whose potential is zero. Metals with a higher ability to release electrons have a negative electrode potential, so they are considered as a cathode. Metals, especially alloys, are inhomogeneous in structure and chemical composition (solid solutions of eutectic mixtures and chemical compounds have different electrode potentials). When some alloys are immersed in an electrolyte, some of its areas have a lower electrode potential, become anode and are destroyed, while other areas of the alloy with a higher potential, as a cathode, remain unchanged. Since there are many such anode and cathode regions, it is considered that the alloy consists of a large number of anodes and cathodes. Metal or alloy joints can also have an increased tendency to corrosion (for example, a joint between a sheet made of aluminum alloy - anode and a brass screw - cathode, where the sheet is subject to corrosion destruction) [7].

\section{METAL CORROSION IN AUTOMOTIVE PARTS}

Corrosion on motor vehicles occurs in several forms. Characteristic vehicle areas affected by corrosion are: bearing elements, exhaust system, braking system, driving system, cooling system parts, engine parts (pistons and cylinders). General corrosion is the most common type of corrosion on vehicles that occurs on the outer metal panels of the vehicle body and chassis, Figure 1a. The result of such corrosion is occurence of surface damage, which impairs the appearance of the vehicle and prevents the proper operation of the vehicle, due to which the vehicle loses its resale value. General corrosion also affects the underside of the vehicle and the vehicle frame, which can lead to surface damage to the floor plate and weakening of the frame. The most common type of general corrosion on a vehicle is uneven general corrosion. It affects individual parts and vehicle areas that are located in zones 
suitable for its acting. Pitting occurs when the metal parts come into contact with chlorides and other chemical species. This can cause a corrosive reaction locally producing small cavities. Due to the existence of these small cavities, there is a leak in the radiator and in the muffler and tail pipe (pitting inside tail pipe is shown in the Figure 1b). Corrosion inhibitors are added to the coolant to prevent corrosion of the cooling system.

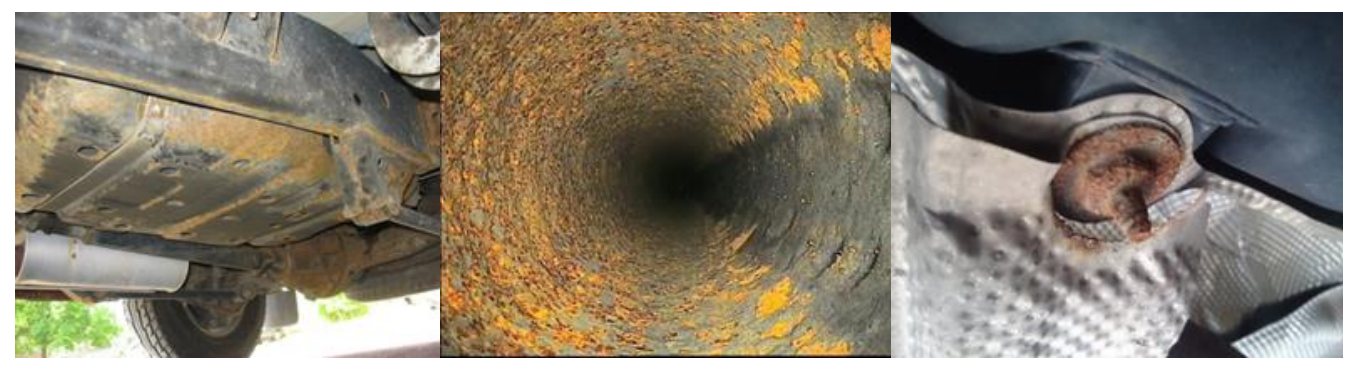

Figure 1 Forms of vehicle corrosion: a) general corrosion of vehicle body panels, b) pitting in the tail pipe, c) Contact corrosion between two different metals

Galvanic (contact) corrosion occurs when different metals are in contact, where one of the metals is more electrochemically active and corrodes, while the other metal is protected by this corroded metal, Figure 1c. Galvanic corrosion was considered more as a cosmetic damage and disadvantage at a time when more metals were combined for decoration of vehicles (nowadays, this is no longer the case). The occurrence of galvanic corrosion can be significantly reduced by the correct design of the vehicle, but its action must certainly be borne in mind when different materials are used in the construction of the vehicle. Corrosion in gaps (crevice) occurs when fluid penetrates into narrow gaps between two surfaces, e.g. between a steel support and washer on a windshield wiper, etc. The fluid can concentrate in a narrow gap causing severe corrosion.

\subsection{Causes of corrosion on vehicles}

There are several factors that affect the occurrence of corrosion on vehicles, which are related to the process of vehicle design, the production process and the working conditions themselves [4].

\subsubsection{Vehicle design}

It happens that in the process of a vehicle design, a wrong design solution is adopted sometimes, which can be the reason that corrosion appears on vehicle in use. Therefore, some design requirements for corrosion protection should be met at the vehicle design stage. Namely, it is necessary to avoid direct contact between metals that have different corrosion potential, to avoid designing cracks and gaps in which fluids, salt and road impurities can accumulate. The choice of material during vehicle design can also significantly affect the later occurrence of corrosion. In order for the vehicle to be in use for as long as possible without corrosion, it is necessary to use corrosion-resistant metals, apply appropriate surface protection of materials, use polymers, and it is also important to avoid direct contact of different metals. One of the key decisions to be made in the vehicle design phase is the choice of protective paints, varnishes and impermeable coatings. Therefore, nowadays in the automotive industry, it has become the standard to apply protective paints to the entire body of the vehicle, to treat fenders and lower surfaces with special coatings that protect surfaces from impact damage, to minimize the initial occurrence of corrosion. 


\subsubsection{Production process}

It can happen that a good choice of design solutions adopted in the vehicle design phase is almost annulled due to the low quality of production. There are several elements of the production process that are especially important from the point of view of vehicle corrosion protection. First, the quality of the welding can affect the appearance of cracks in which corrosion can be initiated. Then, the preliminary preparation of the surfaces should be performed in an appropriate way to ensure a good adhesion of the primer and finishing coatings. Finally, some specific protections such as impact-resistant coatings and sealing coatings can be applied by hand, so that their quality largely depends on the expertise and skill of the workers.

\subsubsection{Vehicle operating conditions}

The characteristics of the environment and atmospheric conditions characteristic for the region where the vehicle is used, such as acid rain, the use of deicing salt in the winter, the influence of the sea climate, strongly influence the occurrence of corrosion on vehicles. In such corrosive environments, the personal habits of the vehicle owner and good maintenance of the vehicle (regular washing, fluid change) come to the fore, which can significantly increase the vehicle's resistance to corrosion.

\section{IMPACT OF CORROSION ON VEHICLE SAFETY}

On the one hand, the impact of corrosion on the safety of vehicle depends on how much the corrosion has spread, and on the other hand, on the function of the structural element that has been corroded. If corrosion has affected a vital structural part of the vehicle, the safety of the vehicle can be endangered even by the appearance of a small amount of corrosion which affects the continuity of the supporting structure, i.e. endangers the load bearing capacity of the structural component. On the other hand, if the corrosion has excessive affected some parts of the vehicle that do not have a load-bearing significance, in that case the corrosion has little or almost no impact on the safety of the vehicle. Corrosion of some specific parts, e.g. door sills, can be very important for one type of vehicle construction, while for another type of construction it may not be significant. Figure 2 shows the structural elements of a passenger vehicle, where the shaded portions indicate the important load bearing parts of various typical vehicle constructions [6]. Certain areas of the vehicle structure are particularly important for the vehicle safety. These areas are:

- Load bearing parts of the vehicle to which other parts of the vehicle are mounted, specially parts that are subject to technical inspection (steering parts, levers and suspension joints, shock absorbers, braking system, seat belts, fenders, bumpers, additional safety systems).

- Any other load bearing or supporting elements or supporting panelling located up to $30 \mathrm{~cm}$ from the mounting location of the parts to be inspected. For example, during the inspection of the vehicle it is necessary to check the seat belts are attached to the inner sill, but it is also necessary to check the condition of the outer sill (or its reinforcements if the outer sill is made of plastic cover), door pillar, floor panels or any other structural element within $30 \mathrm{~cm}$ from the seat belt mounting point. 


\section{ANALYSIS OF THE IMPACT OF CORROSION TO THE VEHICLE CHASSIS}

A chassis of a motor vehicle is a load bearing part which can be considered as the "backbone" of each vehicle. It should be strong enough to bear any type of load, regardless of the difficult operating conditions (fully loaded vehicle or empty vehicle). The chassis (frame) consists of two longitudinal girders and several transverse connecting girders. Some types of frames have cut-outs in various shapes primarily for weight reduction. The typical materials from which the chassis are built are various types of alloy steels. Chassis parts are most often made from I, C or U profiles. During design process of the vehicle, based on the assumed and experimental values of static and dynamic loads, the chassis as the load bearing part should be dimensioned, taking into account a certain safety factor due to the assumption of possible weakening of the structure, potential overload and the impact of corrosion. It is assumed that the weakening of the chassis due to corrosion will violate the characteristics of the predicted factory load capacity and safety parameters of the operation that the vehicle had at the beginning of its working life.

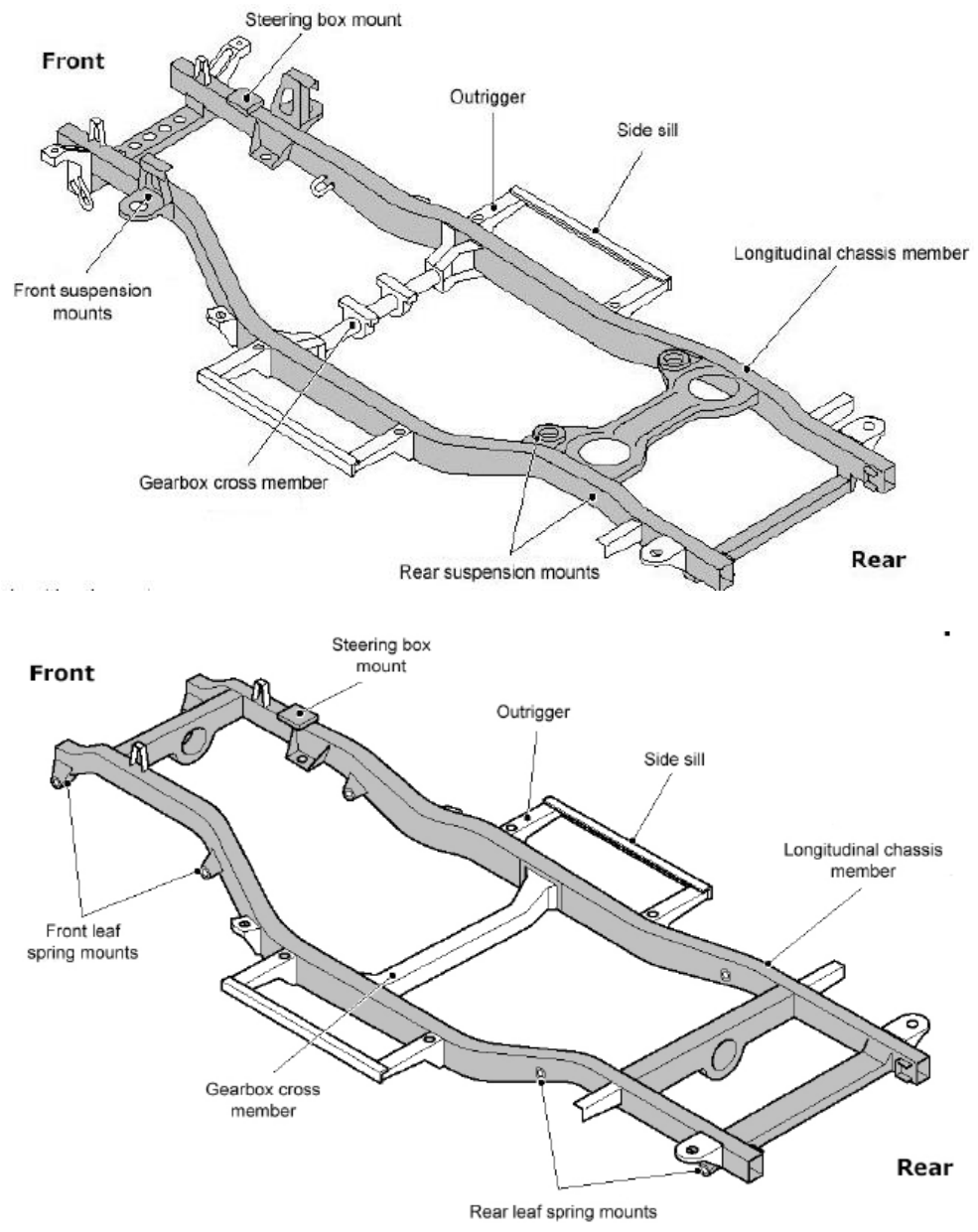

Figure 2 The important load bearing partsof a passenger vehicle 


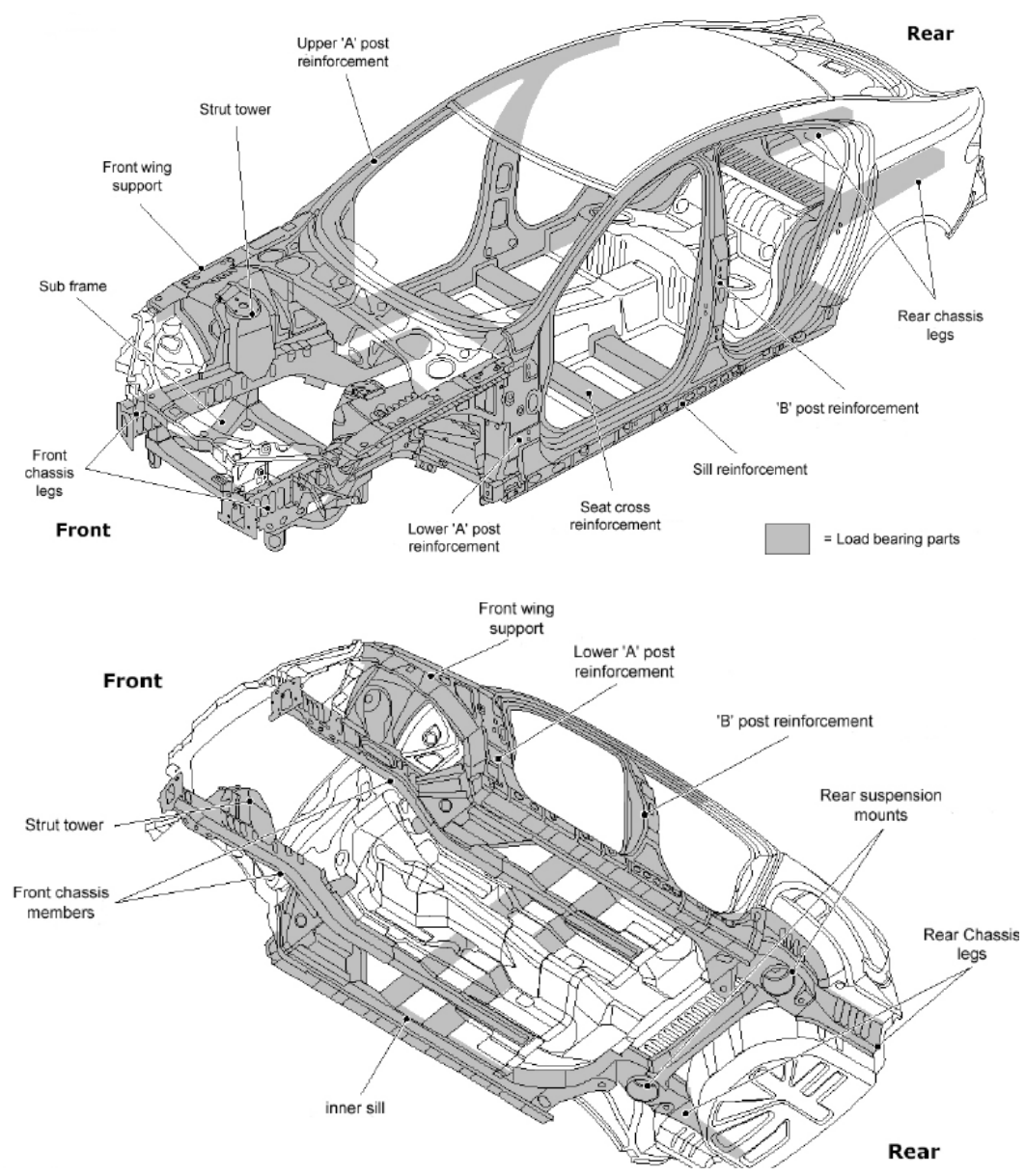

Figure 2 Continued

In this paper, we analyzed the influence of general corrosion to the chassis, in a way that influence of corrosion was simulated by reducing the thickness of the chassis profile [1]. We take an assumption that the corrosion is uniformly distributed, i.e. the thickness of the bearing elements decreases uniformly due to corrosion (although an unevenly distributed corrosion is the most common case in reality). Also, by reducing the thickness of the profile, some critical areas can be identified to which additional attention should be paid, both during the design process and in inspection of the chassis condition in exploitation. We used the SolidWorks simulation package for FEM analysis [9]. We analyzed the chassis for three cases of static load:

- Case I - analysis of static load of the factory designed structure (thickness of profile $=8 \mathrm{~mm}$ ),

- Case II - analysis of the chassis of a vehicle which has been operated for 20 years (thickness of profile $=7.4 \mathrm{~mm}$ ),

- Case III - analysis of the chassis of a vehicle which has been operated for 30 years (thickness of profile $=6.5 \mathrm{~mm}$ ). 
For all three cases of analysis, all input parameters are the same, only the profile sheet metal (longitudinal and transverse) changed its thickness due to the action of corrosion. According to the available empirical data from the literature, the degree of corrosion action is about $0.02 \mathrm{~mm}$ in material decrease per year. The relationship between time and material decrease is not linear. At the beginning of vehicle operation, the effect of corrosion is minimal due to good protection of the surface layer of the metal parts, but with the passing of time and the negative effects of operating conditions, the degree of protection of the chassis surface decreases and the amount of removed material increases. The effect of corrosion is especially increased if the structural element is mechanically damaged.

\subsection{A design chassis data}

For the purposes of this analysis, the chassis of the Mercedes-Benz Actros 3344s / 33 truck was chosen. All the necessary data has been taken from the official Mercedes website and the Actros Mercedes specification (a document intended to inform potential customers) [8].

\subsubsection{Material properties and dimensions}

The material from which the chassis is made is alloy steel DIN 1.0984, with following mechanical properties: density $=7800 \mathrm{~kg} / \mathrm{m}^{3}$, minimum yield strength $\mathrm{ReH}=500(\mathrm{MPa})$, tensile strength $\mathrm{Rm}=700(\mathrm{MPa})$, Young's modulus of elasticity $=210000(\mathrm{MPa})$, Poisson's ratio $=0.28$, shear modulus $=79000(\mathrm{MPa})$. Figure 3 shows dimensions of the analyzed chassis.
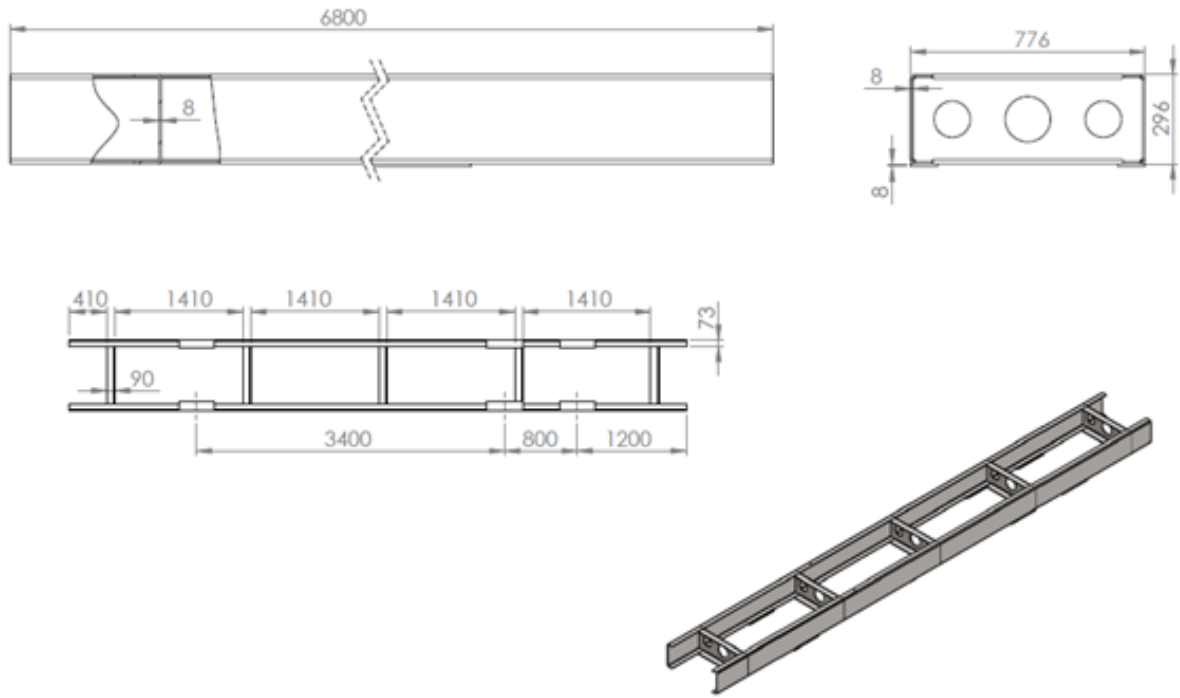

Figure 3 Dimensions of the analyzed chassis [1]

The load capacity of the truck is $24 \mathrm{t}$, and it is assumed that the force of gravity of the load acts in the middle of the cargo space.

\subsubsection{Chassis supports (same for all three cases of analysis)}

The support of the chassis represents location where contact between the chassis and the truck axle is made. The chassis transmits force to the axles via the supports and further to the ground. In the analysis, slider-shaped supports were taken for 4 supports, while 2 supports were fixedly connected, Figure 4. 


\subsubsection{Forces acting to the chassis (same for all three cases of analysis)}

The chassis is loaded by external load forces and forces due to the weight of the frame, Figure 5. Force 1 represents the weight of the load from the cargo space and the weight of the body above the rear axles. Force 2 represents the force due to the weight of the body part above the front axle. This analysis was done for the loads prescribed by the manufacturer.

\subsubsection{FEM model mesh (same parameters in all three cases of analysis)}

In FEM analysis, the structure was devided by 21448 elements of standard shape (equilateral triangle), with 45278 nodes.
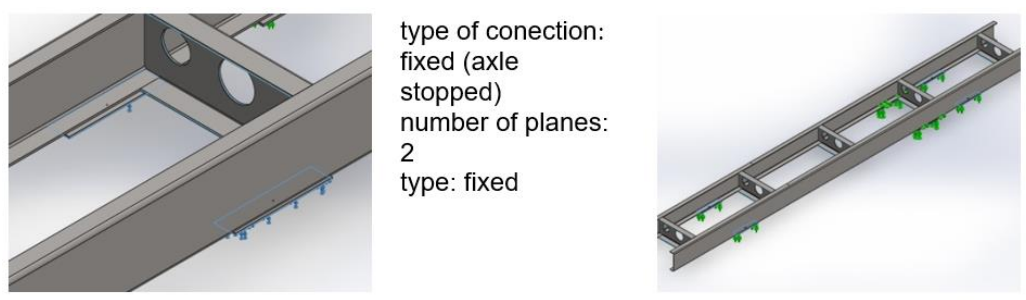

type of conection:

free

number of planes: 4 type: sliders

Figure 4 Type of supports [1]

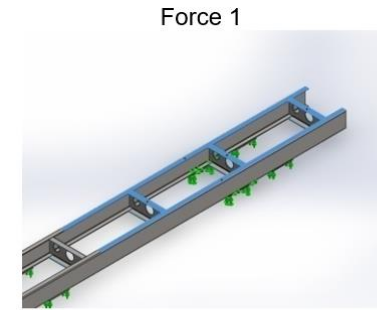

number of planes: 5 type: normal force value: $265000 \mathrm{~N}$

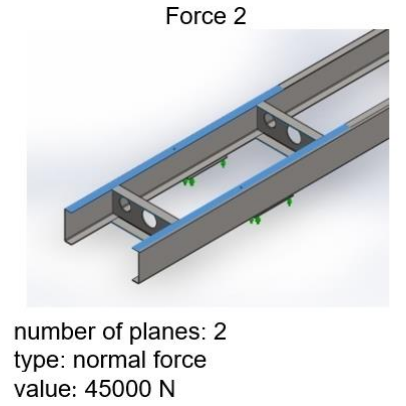

referent plane: upper plane value: mass $\times 9,81 \mathrm{~N}$

Figure 5 Forces acting to the chassis [1]

\section{RESULTS OF ANALYSIS}

In the FEM analysis, 4 parameters were analyzed:

- $\sigma$ - stress

- $\mu$ - displacement, refers to the total displacement of nodes,

- $\varepsilon$ - specific elongation, refers to the elongation of individual elements,

- $\mathrm{K}$ - safety factor, the value is calculated based on the actual stress and the allowable stress for a given material, indicating how many times the allowable stress is greater than the actual stress.

The objectives of this analysis are as follows:

- identification of critical areas of the structure,

- obtaining results which could show the extent to which corrosion has weakened the frame (change of safety factor).

The values of parameters obtained by FEM analysis are shown in Table 1, while corresponding diagrams are shown in Figures $6-8$. 
Table 1 The values of analyzed parameters

\begin{tabular}{|l|c|c|c|c|c|}
\hline & $\begin{array}{c}\text { Thickness } \\
\text { of long. } \\
\text { and transv. } \\
\text { profiles } \\
\mathrm{t}(\mathrm{mm})\end{array}$ & $\sigma(\mathrm{N} / \mathrm{mm} 2)$ & $\mu(\mathrm{mm})$ & $\begin{array}{c}\text { Specific } \\
\text { elongation } \\
\text { (for chosed } \\
\text { surface of } \\
\text { frame) } \\
\varepsilon\end{array}$ & $\begin{array}{c}\text { Min. } \\
\text { safety } \\
\text { factor }\end{array}$ \\
\hline Case I & 8,00 & 250,14 & 3,20 & 0,101 & $\mathrm{~K}$ \\
\hline $\begin{array}{l}\text { Case } \\
\text { II }\end{array}$ & 7,40 & 296,46 & 3,90 & 0,122 & 1,41 \\
\hline $\begin{array}{l}\text { Case } \\
\text { III }\end{array}$ & 6,50 & 370,80 & 4,70 & 0,131 & 1,11 \\
\hline
\end{tabular}
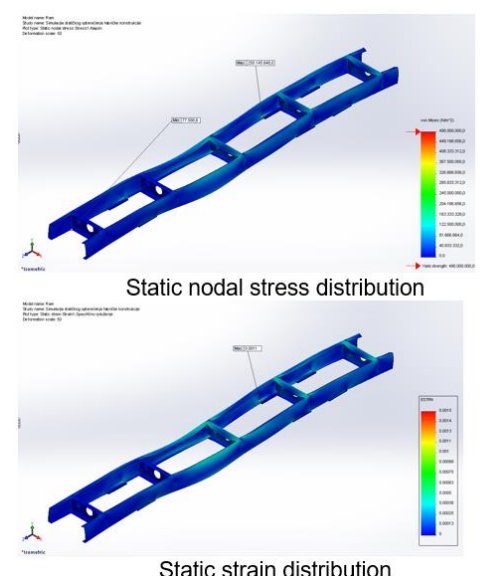

Static strain distribution

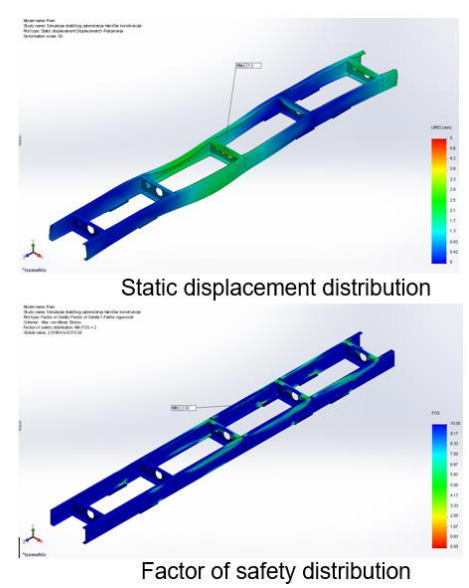

Figure 6 Results of analysis of static load of the factory designed structure $(t=8 \mathrm{~mm})$ [1]
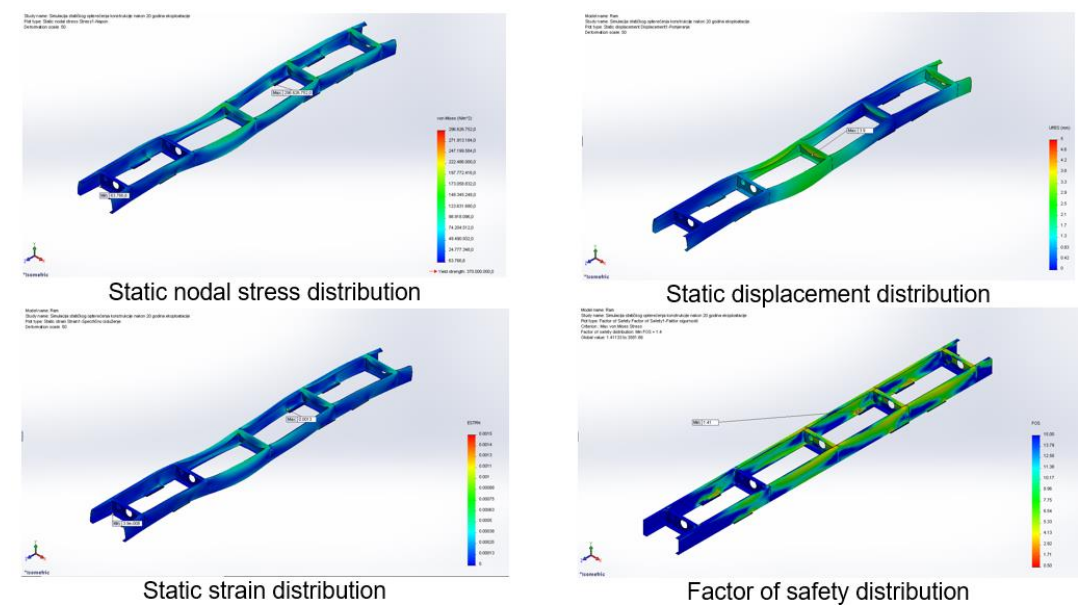

Figure 7 Results of analysis of the chassis of a vehicle which has been operated for 20 


$$
\text { years }(t=7.4 \mathrm{~mm})[1]
$$
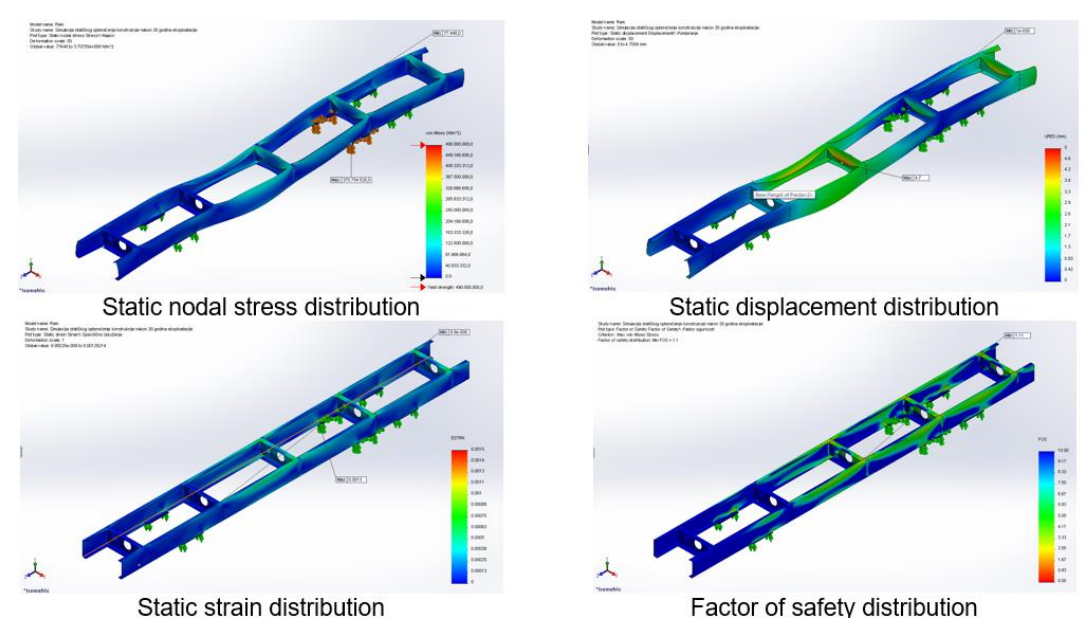

Figure 8 Results of analysis of the chassis of a vehicle which has been operated for 30 years $(t=6.5 \mathrm{~mm})[1]$

\section{DISCUSSION OF RESULTS}

This analysis especially emphasizes the results obtained in the form of recognized critical areas of the structure, as well as areas that are not exposed to high loads. Critical areas are those with high values of stresses, displacements, specific elongations and areas where safety factor has a minimum value. Based on the analysis, critical areas of the structure are defined as follows:

- locations where profiles are connected,

- locations of concentrated load acting,

- locations where profiles are supported (locations provided for profiles support on axles),

- intentionally weakened locations due to weight saving.

From the Figure 9, one can notice that the maximum value of the internal stress is at the location where frame is supported to the shafts. The stress value for other critical points is also close to the maximum. The minimum value of the safety factor is at the point of connection between two profiles, which are also the most loaded point due to the action of the weight of the load from the cargo space. The largest displacement occurred on the transverse profile which is also the location where the highest load acts (force 1, force 2 and weight of the frame). At this location the internal stress is close to the maximum, but not the highest. The highest specific elongation is in the lower zone of the longitudinal girders. 

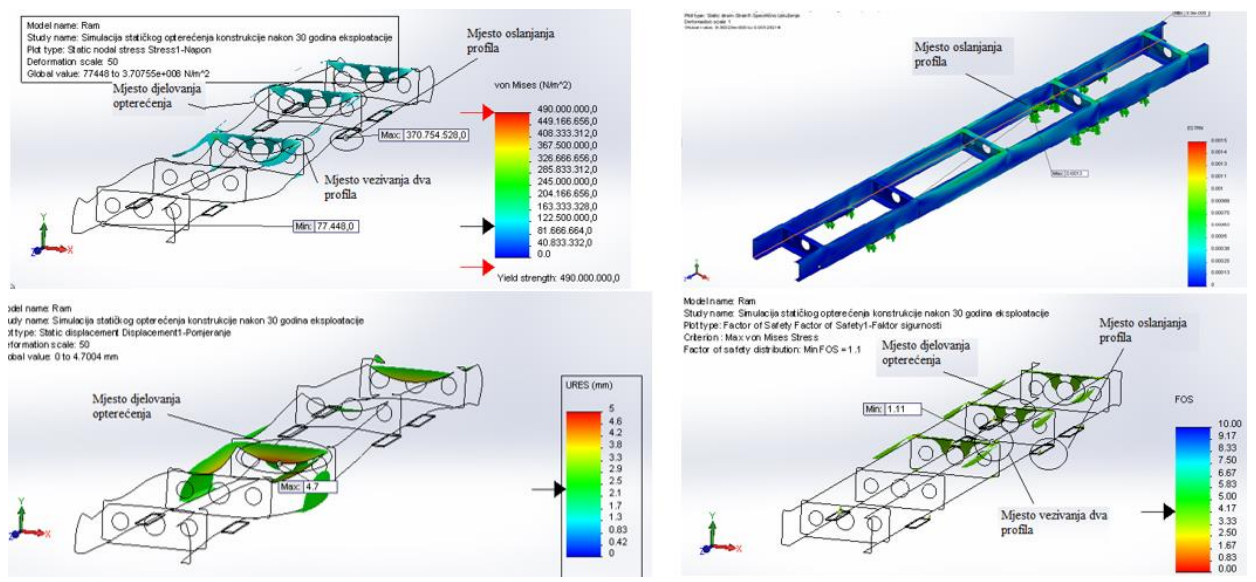

Figure 9 Critical areas of the frame [1]

The theoretical limit value of the safety factor during design is 1 If it happens that the safety factor value decreases below 1 , the frame will be probably plasticly deformed, i.e. the deformations of the frame will be permanent. According to the data given in Table 1, it is obvious that safety factor decreases as the chassis time in exploatation increase. The reduction of the safety factor was expected, and the obtained value leads to the conclusion that the assumption that corrosion has a negative effect to the vehicle frame was correct.

\section{CONCLUSIONS}

Corrosion that occurs on vehicles is a problem that endangers traffic safety, and its negative financial effect is also significant. Corrosion that has occurred on important load-bearing parts of the vehicle reduces their designed strength and rigidity, i.e. the ability to carry the projected load, and thus directly affects the safety of vehicles in traffic. A recognition of critical locations are important for any structure. It is especially important to emphasize that critical locations from the point of view of load are often critical locations from the aspect of corrosion action. Thus, for example, due to the connections between profiles (welds, rivets, wedges, screws), regardless of the fact that the profiles are made of the same material, the corrosion may happened (due to the gaps in which moisture remains, as well as salt). Also, the locations where profile are deformed and locations where material is cut-off due to weight saving are suitable for corrosion action due to the potential poor surface protection or possible mechanical damage. The locations where concentrated loads act are the points of support of the cargo box, the points of support of the cabin, etc. In order to eliminate the effect of corrosion, most manufacturers significantly strengthen the structur's dimensions. According to the data which can be found in literature, the value of the safety factor in design process can be from 3 to 40 . So, overdesign is the way to ensure the structure will be safe, as well its environment. However, the structure can break and fail due to improper operation (overloading), inadequate maintenance, as well as insufficient control of the condition of the vehicle. Therefore, during periodic inspections of vehicles, it is important to determine the condition of the vehicle in terms of corrosion and structural integrity, especially the load-bearing structural elements on which other parts of the vehicle are placed. 


\section{REFERENCES}

[1] Aleksić, M.: "Corrosion of load bearing structures of motor vehicles", bachelor thesis, Faculty of Mechanical Engineering Banja Luka, 2016.

[2] Fujita, S., Kajiyama, H., Kato, C.: "Assessment and Application Technologies for Automotive Materials (Perforation) - Techniques for Corrosion Resistance and Perforation Feedback for Automotive Steel Materials", JFE technical report, 2004, No. 4, pp. 9-16.

[3] Golubović-Bugarski, V., Globočki Lakić, G., Petković, S.: "Corrosinon and structural integrity of vehicles", Profesional Conference Technical inspection of vehicles of Republika Srpska, (organised by University of Banja Luka, Faculty of Mechanical Engineering), 2015.

[4] Johnson, J.T.: "Corrosion Control and Prevention - Appendix N - Motor vehicles", The Body Division of the Automotive Corrosion and Prevention Committee of the Society of Automotive Engineers, 2000.

[5] Koch, G.H., Brongers M.P.H., Thompson N. G.: "Corrosion Costs and Preventive Strategies in the United States", The U.S. Federal Highway Administration, publication no. FHWA-RD-01-156, NACE International, 2002.

[6] MOT Inspection Manual, "Appendix C: Structural integryti and corrosion”, 2011, Vehicle and Operator Services Agency.

[7] Wikipedia, available at: https://en.wikipedia.org/wiki/corrosion, Accessed: 10.09.2020.

[8] Mercedes-benz, available at: https://www.mercedes-benz.com/, Accessed: 10.09.2020.

[9] SOLIDWORKS, available at: https://www.solidworks.com, Accessed: 10.09.2020. 